\title{
Effect of Mobile-Augmented Reality (MAR) in Digital Encyclopedia on The Complex Problem Solving and Attitudes of Undergraduate Student
}

\author{
https://doi.org/10.3991/ijet.v16i07.21223 \\ Alfyananda Kurnia Putra ( $\left.{ }^{\bowtie}\right)$, Sumarmi, Alfi Sahrina, Azni Fajrilia, \\ Muhammad Naufal Islam \\ Universitas Negeri Malang, Malang, Indonesia \\ alfyananda.fis@um.ac.id \\ Batchuluun Yembuu \\ Mongolian National University of Education, \\ Ulan Bator, Mongolia
}

\begin{abstract}
The study aimed to determine the effect of mobile augmented reality in the digital encyclopedia on complex problem-solving ability and responsible decision-making attitude of first-year students. The research was a quasiexperiment (quantitative research) with pretest and posttest methods. The population was first-year students of 2019/2020 in the Geography Education program, Faculty of Social Sciences, State University of Malang. The experimental group was from the PGEO6006-L class, and the control group was from the PGEO6006-A class, totaled 73 participants. Data were collected using a qualitative method using interviews and a quantitative method using a questionnaire for 4 weeks. The data analysis used an independent t-test to determine the effect of mobile augmented reality on students' complex problem-solving ability and responsible decision-making attitude in Cosmography class. The results indicated that mobile augmented reality in the digital encyclopedia has a significant effect on students' complex problem-solving ability and responsible decision-making attitude.
\end{abstract}

Keywords-Mobile Augmented Reality, Digital Encyclopedia, Complex Problem Solving, Attitudes

\section{Introduction}

Technology is a challenge for learning in the era of digital disruption. As a digital native, Generation $\mathrm{Z}$ is facilitated by technology in their learning process [1], [2]. The use of various digital devices in instructional design is a top priority for digital learning [3]. The way to create a digital learning process is to use digital learning media [4].

Digital learning media, a mediator for delivering information, has a central role in the digital learning process. It is flexible and easy to integrate with other interactive 
media so that the learning process becomes more dynamic [5]. The use of learning media is centered on student activities through exploration and development activities independently [6]. Digital learning media is needed to support the competence and capabilities of generation $\mathrm{Z}$ in industry 4.0.

The learning process is different from the previous generation. It is because growing and developing process is closely related to the digital technology environment [7], [8]. The main characteristics of Generation $\mathrm{Z}$ are dominated by network-based learning processes [9], connectivity to various learning sources [10], and faced with a variety of complex task loads [11]. It required students to have skills, which is the complex problem-solving ability.

Complex Problem Solving (CPS) ability has an essential role in the digital learning process. The integration of various technologies requires the use of complex cognitive processes [12], as the primary condition for digital literacy skills [10]. Besides, the trend in future work requires individuals to have complex problem-solving abilities through changing cognitive and technological demands [13]. Therefore, it is necessary to facilitate the formation of CPS capabilities. CPS ability can be facilitated with the right attitude, given the challenges that will be faced by future generation $\mathrm{Z}$ with the phenomenon of disruption in various fields [14].

Managing attitudes is needed in digital disruption. Future demands require generation $\mathrm{z}$ to have an attitude, such as effective communication, negotiation, to making the right decision [15]. Issues that develop in digital distraction lead to changes, unpredictability, high complexity, and unclearness life [16], [17], so that having the responsible decision-making attitude is needed to face the digital distortion. Also, various jobs in the future cannot be predicted due to the disruption [18], [19]. MAR learning is a media in a digital encyclopaedia that prepares students to solve complex problems.

MAR is an innovation in digital learning. MAR is a real form of breakthrough combining the real world and the virtual world [20], with mobile devices, the learning process becomes very flexible and borderless [21]. MAR can help students to learn abstract and complex material contents [22]. The learning topics that require supporting learning media is the Universe and the Solar System in the Cosmography course of Geography class.

The topic has standard learning outcomes, which are the analysis, evaluation, and creating. The achievements support the capability and competency outcomes of graduates. Cosmography has a wide field of study, with various abstract concepts. The broadness of studies and abstract concepts requires an ability to analyze complex problems. Therefore, MAR is a learning tool that helps to learn abstract concepts in the Cosmography course. Students not only master in low order thinking skills but also for complex problem solving (high order thinking skills).

Various relevant studies showed that MAR can effectively increase complex problem-solving. MAR can increase cognitive abilities to solve complex problems [23][25]. The integration of MAR to solve complex problems in the learning process helps apply theories and concepts through diverse cognitive processes [26]-[28]. The study aimed to determine the effect of MAR on CPS ability and student attitudes in the Cosmography course. 


\section{Theoretical Background}

\subsection{Mobile augmented reality}

Digital learning media is the main foundation in understanding MAR. Digital learning media is a mediator for delivering information from communication to digital-based [29]. Digital learning media is a breakthrough in the learning process that provides flexible learning content (space and time) and easy accessibility [4].

MAR is an innovation in the learning process. Augmented reality displays computergenerated data about the real world in real time [30]. MAR can be defined as a media that combine real dimensions with interactive dimensions in space and time using mobile devices [31], [32]. MAR is closely related to the user's virtual interaction with their environment in manipulating objects or information. Therefore, MAR is a medium in learning that has various advantages.

MAR supports the digital learning process. MAR appears to facilitate the learning and education process [33]-[35]. The advantages of MAR can be seen in the intensity of accessibility, which can connect the learning process, both formal and informal [36]. The concept of unlimited learning has an impact on the student learning process independently.

MAR helps explore students' abilities actively and independently. Students can visualize information on objects that are difficult to reach through effective interactions on 3D objects [37]. MAR can increase motivation and cognition by providing meaningful learning experiences for students [38], [39] and increase academic achievement significantly [40].

\subsection{Complex problem solving}

CPS is a new ability in the learning process that students must have. CPS ability can be defined as an ability in learning and is closely related to the ability to solve a problem in the learning process [41]. The ability is part of the Higher Order Thinking Skills (HOTS), which corresponds to the curriculum's outcome in a new educational concept [42]. The ability is important in education because it is closely related to students' psychological condition, the ability to respond, and computer-based assessments [43].

In higher education, the CPS ability is needed in the learning process. The ability helps students' learning process in higher education to face complex task loads and is integrated with technology [44]. Also, massive and complex information requires students to have CPS skills in the learning process [45].

\subsection{Attitude}

Attitude is an essential aspect of the learning process. Attitude is a concept believed by individuals towards an object [46]. Attitudes in the learning process include beliefs, views, and tendencies toward learning materials [47]. Attitude aspect (affective do- 
main) is a competency that must be achieved by instilling character in the learning process. The core competencies of students' social attitudes are cooperation, responsibility, responsiveness, and pro-active learning [48]-[50]. Effective domain must be measured by indicators that refer to variables [51], [52].

\section{$3 \quad$ Method}

The research design used a quasi-experimental study to examine the MAR learning media on students' CPS ability and RDM attitudes on the Universe and the Solar System topics in the Cosmography course. The experimental design was used pretest and posttest of control group design. The experimental group and the control group used the Geographical Inquiry learning model, but it has differentiated the learning media used. The experimental group used MAR learning media in a digital encyclopedia using the Solar System Scope and soIAR applications. Meanwhile, the control group used audiovisual media, which are the journey through the universe video, origins of the universe 101 , and solar system 101 .

The research was conducted in the Cosmography course taught for 2 hours per week in weeks 3-7 (four weeks) of the 2019/2020 academic year. The scope is the formation process of the universe, galaxies, the solar system, and its influence on earth and the sun as a star. There are no specific criteria, all based on a cosmographic curriculum compiled by a team of experts. For four weeks, the experimental group conducted a lot of group analysis using mobile augmented reality.

\subsection{Participant}

Participants are first-year students of the 2019/2020 academic year, in the Geography Education study program, Faculty of Social Sciences, State University of Malang. Based on four population classes, two classes were selected as the research sample that are the PGEO6006-L class as the experimental group and the PGEO6006-A class as the control group. The sample selected using the purposive sampling method. The sample criteria have followed the needs based on the purpose of the study, which is equal abilities seen from the previous assignments score.

Table 1. Distribution based on gender and research group

\begin{tabular}{|l|c|c|}
\hline \multicolumn{1}{|c|}{ Gender } & Experiment Group & Control Group \\
\hline Male & 7 & 13 \\
\hline Female & 29 & 24 \\
\hline Total & 36 & 37 \\
\hline
\end{tabular}

\subsection{Experimental procedure}

The learning activities and instructional media were used the instructional steps of the Geographical Inquiry from McInerney (2009). The steps are as follows: 
Table 2. Experimental research procedures based on the Geography Inquiry learning model

\begin{tabular}{|l|l|}
\hline \multicolumn{1}{|c|}{ Stage } & \multicolumn{1}{c|}{ Student Activity } \\
\hline $\begin{array}{l}\text { Selecting the Object of } \\
\text { Study }\end{array}$ & $\begin{array}{l}\text { Students discussed in a group of 3-4 people to identify phenomena of the universe } \\
\text { and the solar system and the relationship between conditions and activities on the } \\
\text { earth's surface. } \\
\text { The process slowly constructed their knowledge and experience about the universe } \\
\text { so that students can understand the learning objective. }\end{array}$ \\
\hline Data Collection & $\begin{array}{l}\text { Students collected information about the formation process of the universe and so- } \\
\text { lar system. The activity was based on learning resources recommended by the } \\
\text { teacher. The students using AR media, such as SpaceAR, Space 4D, soIAR, JIG- } \\
\text { space, and bigbangAR, to visualize abstraction of objects into concrete and digital } \\
\text { encyclopedia. } \\
\text { The student has trained their ICT literacy skills and cognitive variable complex } \\
\text { problem-solving in the learning experience. }\end{array}$ \\
\hline Data Analysis & $\begin{array}{l}\text { The data obtained were analyzed using literature study methods from various spa- } \\
\text { tial data, spatial reference information, then using AR as the interpretation. } \\
\text { Students' problem structure and problem context skills were trained in a complex, } \\
\text { contextual, and transparent assignment to analyze certain problems or situations. }\end{array}$ \\
\hline $\begin{array}{l}\text { Understanding and Ex- } \\
\text { plaining }\end{array}$ & $\begin{array}{l}\text { Students learned to evaluate evidence, also identified cause and effect of natural } \\
\text { phenomena and the relationships that affect spatial conditions on earth with a geo- } \\
\text { graphic approach (spatial, regional, and environmental). } \\
\text { The ability to integrate and synthesize problems is essential for students. At this } \\
\text { stage, the process was presented explicitly to develop the ability. }\end{array}$ \\
\hline $\begin{array}{l}\text { Students reflected on the topic in groups. The reflections were presented as reports } \\
\text { to the teacher. }\end{array}$ \\
\hline $\begin{array}{l}\text { Evplyaling } \\
\text { understanding and Pre- } \\
\text { senting }\end{array}$ & $\begin{array}{l}\text { Student knowledge and understanding through geographic investigation was pre- } \\
\text { sented based on the group 's perspective. } \\
\text { Conclusion was presented in the written report then shown to peers in the class. } \\
\text { In this stage, students got a lot of input, suggestions, ideas, views from other } \\
\text { groups. So that it raised new knowledge and understanding of the topic content. }\end{array}$ \\
\hline
\end{tabular}

\subsection{Data collection procedure}

The research has qualitative and quantitative data. The qualitative data were obtained through semi-structured interviews with participants regarding the use of MAR media after completing the research. Meanwhile, quantitative data were obtained through the pretest and posttest in the scores based on the CPS indicator, and the student's attitude indicator.

The CPS indicator was referred to Funke \& Frensch (1995) which are experience, cognitive variables, non-cognitive variables, problem structure, problem context, and environmental factors. Meanwhile, the attitude indicator specifically for responsible decision-making attitude was referred to CASEL's (Core of Social and Emotion Competencies) (Kendziora \& Yoder, 2016) which are identifying problems, analyzing situations, solving problems, evaluating, reflecting, and ethical responsibility.

The selection was based on the outcomes that students must have based on the applicable curriculum. The CPS and RDM instruments have been tested for validity (Pearson Correlation) and reliability (Cronbach Alpha). The CPS and RDM instruments were stated valid with results $>0.444$ (20 respondents). Meanwhile, the reliability of the CPS (0.755) and RDM (0.730). 
Determining students' attitudes towards MAR learning media before and after using the questionnaire was used the social and emotional competencies indicator from Kendziora \& Yoder (2016). The questionnaire was made from google form using a 5-point Likert scale with 24 questions. Interviews were conducted in groups of 4-5 students at the end of the learning session, with a duration of 15-20 minutes.

\subsection{Data analysis}

The data analysis technique was used SPSS 24 by using the normality test, homogeneity, and t-test (independent sample t-test). The results of the per-item normality test> 0.05 and homogeneity> 0.05 (1.00). The t-test was used to determine the significant differences in CPS achievement and student attitudes in both the experimental and control classes. The independence t-test was chosen by considering the significant differences in each class (experimental and control groups).

\section{$4 \quad$ Results}

The study aimed to determine the effect of MAR media on students' CPS ability and RDM attitude. The instructional design referred to the geographical inquiry learning model from McInerney et al. (2009), which is selecting the object of study, data collection, data analysis, understanding and explaining, evaluating, and presenting. The Geographical Inquiry model was used as the instructional design of learning to determine the effect of MAR media in the digital encyclopedia on the ability of CPS and students' RDM attitudes in learning the Universe and the Solar System topics in Cosmography courses.

\subsection{The effect of MAR on complex problem-solving ability}

The pretest was conducted to determine students' CPS abilities before using learning media. The results revealed no significant difference in the pretest of the control group and the experimental group presented in table 3 with a significance score of 0.715 (p> $0.05)$. Also, the mean pretest scores' significance showed not much different from $\mathrm{M}_{\mathrm{Exp}}=65$ and $\mathrm{M}_{\mathrm{Con}}=66$.

Table 3. T-test scores for CPS on the pretest of the control and experimental groups

\begin{tabular}{|l|c|c|c|c|c|c|}
\hline & \multicolumn{2}{|c|}{$\begin{array}{c}\text { Levene's Test for } \\
\text { Equality of Variances }\end{array}$} & \multicolumn{4}{c|}{ t-test for Equality of Means } \\
\hline $\begin{array}{l}\text { Pretest } \\
\text { Score }\end{array}$ & $\boldsymbol{F}$ & Sig. & $\boldsymbol{t}$ & Sig. (2-tailed) & Mean Difference & Std. Error Difference \\
\cline { 2 - 7 } & .080 & .778 & .366 & .715 & .194 & .529 \\
\hline
\end{tabular}

The posttest was given after treatment. The results in table 4 showed that there is a significant difference between the mean posttest scores of the experimental group $\left(\mathrm{M}_{\mathrm{Exp}}=76\right)$ and the control group $\left(\mathrm{M}_{\mathrm{Con}}=69\right)$ with a significance score of $0.000(\mathrm{p}$ 
$<0.05)$. The MAR has a positive influence on students' CPS ability in the Cosmography course on the Universe and the Solar System topic.

Table 4. T-test scores for CPS on the posttest of the control and experimental groups

\begin{tabular}{|l|c|c|c|c|c|c|}
\hline & $\begin{array}{c}\text { Levene's Test for Equality } \\
\text { of Variances }\end{array}$ & \multicolumn{4}{|c|}{ t-test for Equality of Means } \\
\hline $\begin{array}{l}\text { Posttest } \\
\text { Score }\end{array}$ & $\boldsymbol{F}$ & Sig. & $\boldsymbol{t}$ & Sig. (2-tailed) & Mean Difference & Std. Error Difference \\
\cline { 2 - 7 } & 3.776 & .056 & -12.168 & .000 & -7.431 & .611 \\
\hline
\end{tabular}

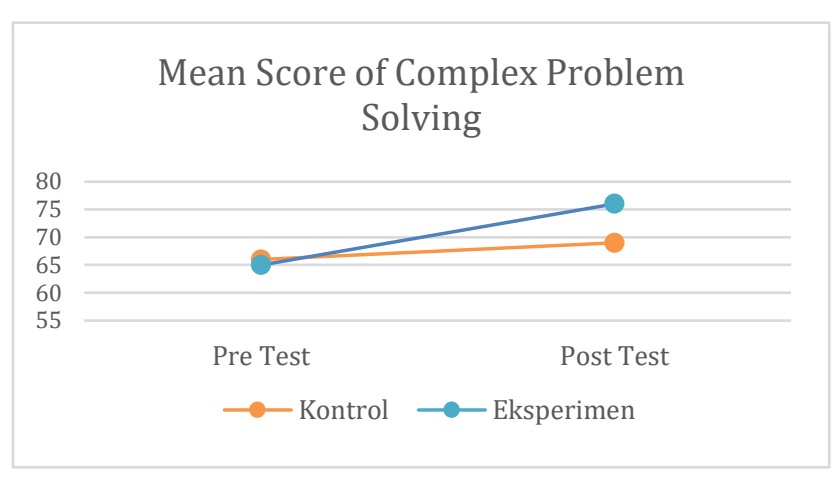

Fig. 1. The mean scores of Complex Problem Solving on pretest and posttest

\subsection{The effect of MAR on responsible decision making attitude}

The study measured the initial scores of students' RDM attitudes by conducting a pretest before using learning media. The scores were obtained from the experimental group $(\mathrm{MExp}=63)$ and the control group $(\mathrm{MCon}=66)$. The significance can be seen in table 5.

Table 5. The t-test scores of students attitude on the pretest of control and experimental groups

\begin{tabular}{|c|c|c|c|c|c|c|}
\hline & \multicolumn{2}{|c|}{$\begin{array}{c}\text { Levene's Test for } \\
\text { Equality of Variances }\end{array}$} & \multicolumn{4}{c|}{ t-test for Equality of Means } \\
\hline \multirow{2}{*}{ Pretest Score } & $\boldsymbol{F}$ & Sig. & $\boldsymbol{T}$ & $\begin{array}{c}\text { Sig. } \\
(2-\text {-tailed })\end{array}$ & Mean Difference & Std. Error Difference \\
\cline { 2 - 7 } & 2.236 & .139 & 5.783 & .000 & 2.952 & .510 \\
\hline
\end{tabular}

The significance scores showed the difference in the average attitude of students in the posttest results of the experimental and control groups, which is $\mathbf{M}_{\mathrm{Exp}}=78$ and $M_{\text {Con }}=67$. The MAR has a positive effect on the students' RDM attitudes on the Cosmography course, especially in the Universe and the Solar System topic. 
Table 6. The t-test scores of students attitude form the post-test of control and the experimental groups

\begin{tabular}{|l|c|c|c|c|c|c|}
\hline & \multicolumn{2}{|c|}{$\begin{array}{c}\text { Levene's Test for Equal- } \\
\text { ity of Variances }\end{array}$} & \multicolumn{4}{|c|}{ t-test for Equality of Means } \\
\hline $\begin{array}{l}\text { Posttest } \\
\text { Score }\end{array}$ & $\boldsymbol{F}$ & Sig. & $\boldsymbol{t}$ & $\begin{array}{c}\text { Sig. } \\
(2-\text { tailed) }\end{array}$ & Mean Difference & Std. Error Difference \\
\cline { 2 - 7 } & .609 & .438 & -13.266 & .000 & -10.359 & .781 \\
\hline
\end{tabular}

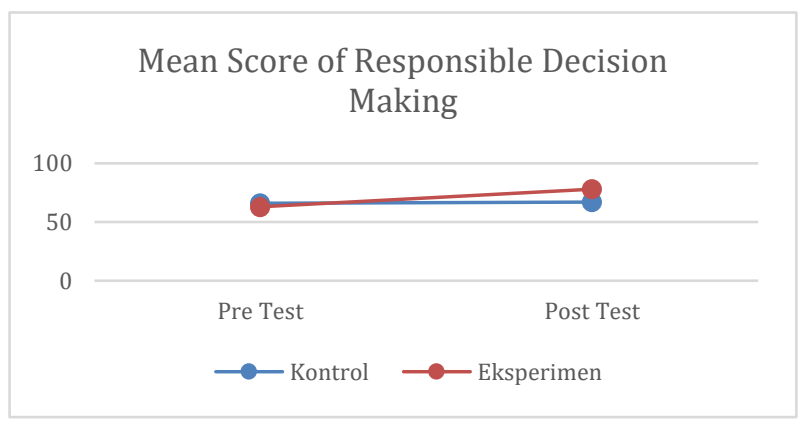

Fig. 2. The mean scores of Responsible Decision Making on pretest and posttest

\subsection{Student opinion of MAR in a digital encyclopedia on the Cosmography course}

The qualitative data were collected using a semi-structured interview method. The interview was used to determine the students' opinions in using MAR. The interview activity was based on several aspects: the advantages of MAR learning media, the lack of MAR as a medium, and the expectation of using MAR in Cosmography courses. The results of the interview were listed from the student's answer.

The interview showed that MAR provides various conveniences in the learning process. MAR provides convenience through a variety of potential features in it. The ease is obtained through the acquisition of meaningful experiences [53] and active learning [23]. Students gave positive ideas about MAR in the Cosmography course. Following are the students' opinions:

"MAR visualization helps to improve understanding of abstract concepts, especially in the Universe and the Solar System topic. Also, there are various illustrations and information to help the learning to process actively and independently."

"The interactive impression using MAR helps students in the learning process by connecting the physical and virtual environments."

Moreover, students argue that the use of MAR has shortcomings, mainly related to personal accessibility. Also, the lack of MAR can affect student interest in the Cosmography courses. 
"MAR is very dependent on the devices used, and not every device owned by students can access MAR. Such conditions affect student interest to apply MAR in learning activities."

Other studies regarding student responses in implementing MAR in the Cosmography course are related to student expectations using MAR. The results showed that students have high expectations in the learning process. Besides, MAR has high expectations in its application to other subjects, especially to achieve an effective and efficient learning process.

"The novelty of using MAR in the Cosmography course makes the learning process effective and efficient. The various advantages in it make MAR have an excellent opportunity to be used in the Cosmography course and other courses."

"The novelty of using MAR in the Cosmography course makes the learning process effective and efficient. The various advantages in it make MAR have an excellent opportunity to be used in the Cosmography course and other courses."

\section{Discussion}

MAR in the digital encyclopedia was used as a learning medium to measure the effect of MAR on students' CPS ability and RDM attitude in the Universe and the Solar System topics in the Cosmography course. The results revealed that MAR in a digital encyclopedia could increase complex problem-solving ability. Its increase is due to the supporting features of visualization and complex objects [54]-[56].

In the beginning, the CPS ability and RDM attitude in control and experimental groups showed no significant difference. It is because there has been no special treatment for the two groups. Table 4 revealed that there is a positive effect with a significance value (0.000). The Geographical Inquiry model encourages CPS capabilities through indicators of integrating future knowledge [57]. The same results can be seen in the RDM student attitude variable.

MAR in the digital encyclopedia used in the Geographical Inquiry model effectively influences students' RDM attitudes. The RDM attitude is obtained through an inquiry process on the indicators presented [58]. The attitude of RDM is influential if the right instructional design is used [59] and the right learning media.

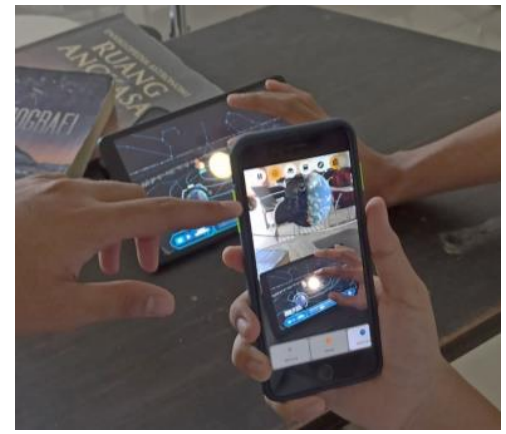

Fig. 3. Student learning activities in using Mobile Augmented Reality 
MAR facilitated student activity to select indicators for the study and data collection, and students can interact directly between physical and virtual experiences. It formed a meaningful learning experience, independence, motivation, and affects science process skills [60]. The solving problems were formed through personal experience, deep exploration activities, complexity, and dynamic learning [61], [62]. The use of MAR provides a better evaluation of problem identification [63].

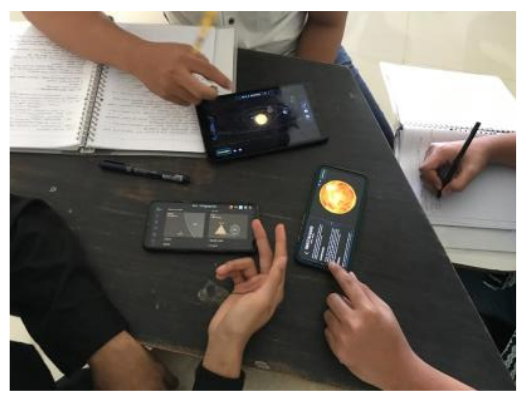

Fig. 4. The process of integrating, synthesizing and data analysis by students

The process of integrating, synthesizing problems, and analyzing data could directly develop CPS abilities. The process is obtained through structured assignments with a high burden of complexity to improve the problem structure and context's cognitive aspects. Structured assignments can improve student analysis [64].

Students have an adequate opportunity to share and discuss the process of the universe. The intense communication process in learning made it easier to identify and explain complex cause-and-effect relationships from forming the universe. Emphasis on cognitive variables requires students to construct and synthesize their previous knowledge with new knowledge, thus providing a meaningful learning experience [65].

In the evaluation indicator, students did a reflection on learning activities. The activities represented knowledge gained during the learning process. The ability is related to the non-cognitive aspects of the variable through self-confidence, motivation, and interest in the learning process. The RDM attitude raised through learning activities at this stage is evaluated and reflected in studying learning material [66].

The outcome of students' CPS ability and RDM attitude can be seen while applying geographical understanding and presenting. In this activity, students are asked to present their studies or discussions with colleagues in class. In learning activities, it can be seen that the perspective of geography is used as a unit of analysis in understanding and studying content. CPS ability is related to the environmental factors of students by providing various feedback and brainstorming. The various inputs that have been received have led to the RDM attitude of ethical responsibility in responding to various input from peers and teachers. 


\section{Conclusion}

The study aimed to determine the effect of mobile augmented reality on students' complex problem-solving ability and responsible decision-making attitudes. The results showed that mobile augmented reality had a significant positive effect on the students' complex problem-solving ability and responsible decision-making attitude. The advantages of MAR in the learning process are facilitating students' CPS ability through independent exploration activities and presenting new learning experiences for students. Students can actively and independently improve their cognitive abilities in solving complex problems. Also, MAR can help improve students' RDM attitudes by assisting students in determining the appropriate attitude in facing a problem in the learning process. Emphasis on exploring makes students able to answer complex problems and is supported by the right decision-making attitude.

\section{$7 \quad$ Acknowledgement}

The research was supported by the Department of Research and Community Service (LP2M) of State University of Malang based on the rector decree number 3.3.16/ $\mathrm{UN} 32 / \mathrm{KP} / 2020$ about the recipients of research and community service funds of PNBP funding sources for 2020 .

\section{References}

[1] Y. B. D. Kolikant, "Digital natives, better learners? Students' beliefs about how the Internet influenced their ability to learn," Comput. Human Behav., vol. 26, no. 6, pp. 1384-1391, 2010. https://doi.org/10.1016/j.chb.2010.04.012

[2] M. Prensky, "Digital Natives, Digital Immigrants," in From Digital Natives to Digital Wisdom: Hopeful Essays for 21st Century Learning, 2014. https://doi.org/10.4135/97814 $\underline{83387765 . n 6}$

[3] K. R. Green and H. L. Chewning, "The Fault in our Systems: LMS as a Vehicle for Critical Pedagogy," TechTrends, vol. 64, pp. 1-9, 2020. https://doi.org/10.1007/s11528-020-00480$\underline{\mathrm{w}}$

[4] E. Kümmel, J. Moskaliuk, U. Cress, and J. Kimmerle, "Digital learning environments in higher education: A literature review of the role of individual vs. social settings for measuring learning outcomes," Educ. Sci., vol. 10, no. 3, p. 78, 2020. https://doi.org/ $\underline{10.3390 / \text { educsci } 10030078}$

[5] A. Skulmowski and G. D. Rey, "Subjective cognitive load surveys lead to divergent results for interactive learning media," Hum. Behav. Emerg. Technol., vol. 2, no. 2, pp. 149-157, 2020. https://doi.org/10.1002/hbe2.184

[6] R. Hobbs and S. Tuzel, "Teacher motivations for digital and media literacy: An examination of Turkish educators,” Br. J. Educ. Technol., vol. 48, no. 1, pp. 7-22, 2017. https://doi. org/10.1111/bjet.12326

[7] M. Alkhattabi, "Augmented reality as e-learning tool in primary schools' education: Barriers to teachers' adoption," Int. J. Emerg. Technol. Learn., vol. 12, no. 2, pp. 91-100, 2017. https://doi.org/10.3991/ijet.v12i02.6158 
[8] A. Kesharwani, "Do (how) digital natives adopt a new technology differently than digital immigrants? A longitudinal study," Inf. Manag., vol. 57, no. 2, p. 103170, 2020. https://doi.org/10.1016/j.im.2019.103170

[9] J. Wakefield and J. K. Frawley, "How does students' general academic achievement moderate the implications of social networking on specific levels of learning performance?" Comput. Educ., vol. 144, no. June 2019, p. 103694, 2020. https://doi.org/10.1016/ j.compedu.2019.103694

[10] I. Blau, T. Shamir-Inbal, and O. Avdiel, "How does the pedagogical design of a technologyenhanced collaborative academic course promote digital literacies, self-regulation, and perceived learning of students?" Internet High. Educ., vol. 45, p. 100722, 2020. https://doi.org/10.1016/j.iheduc.2019.100722

[11] P. A. Kirschner and P. De Bruyckere, "The myths of the digital native and the multitasker," Teaching and Teacher Education. pp. 135-142, 2017. https://doi.org/10.1016/j.tate.2017. $\underline{06.001}$

[12] S. Vanbecelaere, K. Van den Berghe, F. Cornillie, D. Sasanguie, B. Reynvoet, and F. Depaepe, "The effects of two digital educational games on cognitive and non-cognitive math and reading outcomes," Comput. Educ., vol. 143, p. 103680, 2020. https://doi.org/10.1016/ j.compedu.2019.103680

[13] M. L. Wilson, A. D. Ritzhaupt, and L. Cheng, "The impact of teacher education courses for technology integration on pre-service teacher knowledge: A meta-analysis study," Comput. Educ., vol. 156, p. 103941, 2020. https://doi.org/10.1016/j.compedu.2020.103941

[14] T. Issa and P. Isaias, "Internet factors influencing generations Y and Z in Australia and Portugal: A practical study," Inf. Process. Manag., vol. 52, no. 4, pp. 529-617, 2016. https://doi.org/10.1016/j.ipm.2015.12.006

[15] E. Shliakhovchuk, "After cultural literacy: new models of intercultural competency for life and work in a VUCA world," Educ. Rev., vol. 0, no. 0, pp. 1-22, 2019. https://doi.org/10.1080/00131911.2019.1566211

[16] O. Kohnke, "It's not just about technology: The people side of digitization," in Shaping the Digital Enterprise: Trends and Use Cases in Digital Innovation and Transformation, 2016, pp. 69-91. https://doi.org/10.1007/978-3-319-40967-2_3

[17] P. Vogel and G. Hultin, "Introduction: Digitalization and Why Leaders Need to Take It Seriously," in Conquering Digital Overload, 2018, pp. 1-8. https://doi.org/10.1007/978-3-31963799-0_1

[18] L. Liu, L. Zhang, P. Ye, and Q. Liu, "Influence factors of satisfaction with mobile learning APP: An empirical analysis of China," Int. J. Emerg. Technol. Learn., vol. 13, no. 3, pp. 8799, 2018. https://doi.org/10.3991/ijet.v13i03.8381

[19] D. Lerch, The community resilience reader: Essential resources for an era of upheaval. 2017.

[20] G. J. Hwang, P. H. Wu, C. C. Chen, and N. T. Tu, "Effects of an augmented reality-based educational game on students' learning achievements and attitudes in real-world observations," Interact. Learn. Environ., vol. 24, no. 8, pp. 1895-1906, 2016. https://doi.org/ $\underline{10.1080 / 10494820.2015 .1057747}$

[21] G. Koutromanos, A. Sofos, and L. Avraamidou, "The use of augmented reality games in education: a review of the literature," EMI. Educ. Media Int., vol. 52, no. 4, pp. 253-271, 2015. https://doi.org/10.1080/09523987.2015.1125988

[22] N. A. Adedokun-Shittu, A. H. Ajani, K. M. Nuhu, and A. J. K. Shittu, "Augmented reality instructional tool in enhancing geography learners academic performance and retention in Osun state Nigeria," Educ. Inf. Technol., pp. 1-13, 2020. https://doi.org/10.1007/s10639$\underline{020-10099-2}$ 
[23] S. Y. Chen and S. Y. Liu, "Using augmented reality to experiment with elements in a chemistry course," Comput. Human Behav., vol. 111, no. April, p. 106418, 2020. https://doi. org/10.1016/j.chb.2020.106418

[24] M. Thees, S. Kapp, M. P. Strzys, F. Beil, P. Lukowicz, and J. Kuhn, "Effects of augmented reality on learning and cognitive load in university physics laboratory courses," Comput. Human Behav., vol. 108, p. 106316, 2020. https://doi.org/10.1016/j.chb.2020.106316

[25] J.-C. Yen, C.-H. Tsai, and M. Wu, “Augmented Reality in the Higher Education: Students' Science Concept Learning and Academic Achievement in Astronomy," Procedia - Soc. Behav. Sci., vol. 103, no. 26, pp. 165-173, 2013. https://doi.org/10.1016/j.sbspro.2013.10.322

[26] J. Kim and J. Irizarry, "Evaluating the Use of Augmented Reality Technology to Improve Construction Management Student's Spatial Skills,” Int. J. Constr. Educ. Res., vol. 0, no. 0, pp. 1-18, 2020. https://doi.org/10.1080/15578771.2020.1717680

[27] L. López-Faican and J. Jaen, "EmoFindAR: Evaluation of a mobile multiplayer augmented reality game for primary school children," Comput. Educ., vol. 149, p. 103814, 2020. https://doi.org/10.1016/j.compedu.2020.103814

[28] T. Pipattanasuk and A. Songsriwittaya, "Development of an instructional model with augmented reality technology for vocational certificate students," Int. J. Instr., vol. 13, no. 3, pp. 539-554, 2020. https://doi.org/10.29333/iji.2020.13337a

[29] C. Lange and J. Costley, "Improving online video lectures: learning challenges created by media,” Int. J. Educ. Technol. High. Educ., 2020. https://doi.org/10.1186/s41239-020$\underline{00190-6}$

[30] C. Juan, W. YuLin, W. Tjondronegoro Dian, and S. Wei, "Construction of interactive teaching system for course of mechanical drawing based on mobile augmented reality technology,” Int. J. Emerg. Technol. Learn., vol. 13, no. 2, pp. 126-139. 2018. https://doi. org/10.3991/ijet.v13i02.7847

[31] A. B. Craig, Understanding Augmented Reality: Concepts and Applications. 2013.

[32] A. Sánchez Riera, E. Redondo, D. Fonseca, and I. Navarro, "Construction processes using mobile augmented reality: A study case in building engineering degree," 2013. https://doi.org/10.1007/978-3-642-36981-0_100

[33] C. Muali, P. Setyosari, P. Purnomo, and L. Yuliati, "Effects of Mobile Augmented Reality and Self-Regulated Learning on Students' Concept Understanding," Int. J. Emerg. Technol. Learn., vol. 15, no. 22, p. 218, 2020. https://doi.org/10.3991/ijet.v15i22.16387

[34] M. Omar, D. F. Ali, M. Mokhtar, N. M. Zaid, H. Jambari, and N. H. Ibrahim, "Effects of Mobile Augmented Reality (MAR) towards students' visualization skills when learning orthographic projection,” Int. J. Emerg. Technol. Learn., vol. 14, no. 20, pp. 106-119, 2019. https://doi.org/10.3991/ijet.v14i20.11463

[35] M. Pedaste, G. Mitt, and T. Jürivete, "What is the effect of using mobile augmented reality in K12 inquiry-based learning?," Education Sciences. 2020. https://doi.org/10.20944/preprints202003.0026.v1

[36] M. C. Costa, A. Manso, and J. Patrício, "Design of a mobile augmented reality platform with game-based learning purposes," Inf., vol. 11, no. 3, p. 127, 2020, https://doi.org/ 10.3390/info11030127

[37] C. L. Chen and C. C. Wu, Students' behavioral intention to use and achievements in ICTIntegrated mathematics remedial instruction: Case study of a calculus course, vol. 145. Elsevier Ltd, 2020. https://doi.org/10.1016/j.compedu.2019.103740

[38] M. B. Ibáñez, Á. Di Serio, D. Villarán, and C. Delgado Kloos, "Experimenting with electromagnetism using augmented reality: Impact on flow student experience and educational effectiveness," Comput. Educ., vol. 71, pp. 1-13, 2014. https://doi.org/10.1016/j.compedu. $\underline{2013.09 .004}$ 
[39] S. Küçük, S. Kapakin, and Y. Göktaş, "Learning anatomy via mobile augmented reality: Effects on achievement and cognitive load," Anat. Sci. Educ., vol. 9, no. 5, pp. 411-421, 2016. https://doi.org/10.1002/ase. 1603

[40] C. Erbas and V. Demirer, "The effects of augmented reality on students' academic achievement and motivation in a biology course," J. Comput. Assist. Learn., 2019. https://doi.org/10.1111/jcal.12350

[41] J. Funke and P. A. Frensch, "Complex Problem Solving: The European Perspective-10 Years After," in Learning to Solve Complex Scientific Problems, 2019. https://doi.org/10.4324/9781315091938-2

[42] S. Greiff, A. Fischer, S. Wüstenberg, P. Sonnleitner, M. Brunner, and R. Martin, "A multitrait-multimethod study of assessment instruments for complex problem solving," Intelligence, vol. 41, no. 5, pp. 579-596, 2013. https://doi.org/10.1016/j.intell.2013.07.012

[43] R. Scherer, S. Greiff, and J. Hautamäki, "Exploring the Relation between Time on Task and Ability in Complex Problem Solving," Intelligence, vol. 48, pp. 37-50, 2015. https://doi.org/10.1016/j.intell.2014.10.003

[44] R. Hämäläinen, B. De Wever, K. Nissinen, and S. Cincinnato, "What makes the difference - PIAAC as a resource for understanding the problem-solving skills of Europe's highereducation adults," Comput. Educ., vol. 129, pp. 27-36, 2019, https://doi.org/10. 1016/j.compedu.2018.10.013

[45] I. Wopereis, J. Frerejean, and S. Brand-Gruwel, "Information problem solving instruction in higher education: A case study on instructional design," in Communications in Computer and Information Science, 2015, pp. 293-302. https://doi.org/10.1007/978-3-319-28197$1 \_30$

[46] P. Kind, K. Jones, and P. Barmby, "Developing attitudes towards science measures," Int. J. Sci. Educ., vol. 29, no. 7, pp. 871-893, 2007, doi: 10.1080/09500690600909091.

[47] Y. Zhu, J. H. Zhang, W. Au, and G. Yates, "University students' online learning attitudes and continuous intention to undertake online courses: a self-regulated learning perspective," Educ. Technol. Res. Dev., pp. 1485-1519, 2020. https://doi.org/10.1007/s11423-020$\underline{09753-\mathrm{w}}$

[48] C. R. Prihantoro, "The perspective of curriculum in Indonesia on environmental education," Int. J. Res. Stud. Educ., vol. 4, no. 1, pp. 77-83, 2014, doi: 10.5861/ijrse.2014.915.

[49] A. E. Sejati, L. O. Amaluddin, D. N. Hidayati, and S. Kasmiati, "The Effect of Outdoor Study on the Geography Scientific Paper Writing Ability to Construct Student Character in Senior High School,” 2017. https://doi.org/10.2991/seadric-17.2017.22

[50] Derlina, Sabani, and S. Mihardi, "Improved Characters and Student Learning Outcomes through Development of Character Education Based General Physics Learning Model," J. Educ. Pract., vol. 6, no. 21, 2015.

[51] T. Sitzmann, K. Ely, K. G. Brown, and K. N. Bauer, "Self-assessment of knowledge: A cognitive learning or affective measure?” Acad. Manag. Learn. Educ., vol. 9, no. 2, pp. 169191, 2010, doi: 10.5465/AMLE.2010.51428542. https://doi.org/10.5465/amle.9.2.zqr169

[52] D. B. McCoach, R. K. Gable, and J. P. Madura, Instrument development in the affective domain: School and corporate applications. 2013.

[53] S. Mérida-López and N. Extremera, "When pre-service teachers' lack of occupational commitment is not enough to explain intention to quit: Emotional intelligence matters!," Rev. Psicodidáctica (English ed.), vol. 25, no. 1, pp. 52-58, 2020. https://doi.org/10.1016/ j.psicoe.2019.05.001

[54] A. Czauderna and A. Budke, "How digital strategy and management games can facilitate the practice of dynamic decision-making," Educ. Sci., vol. 10, no. 4, p. 99, 2020. https://doi.org/10.3390/educsci10040099 
[55] K. S. McNeal et al., "A multi-institutional study of inquiry-based lab activities using the Augmented Reality Sandbox: impacts on undergraduate student learning,” J. Geogr. High. Educ., vol. 44, no. 1, pp. 85-107, 2020. https://doi.org/10.1080/03098265.2019.1694875

[56] S. Pedersen and M. Liu, "Teachers' beliefs about issues in the implementation of a studentcentered learning environment," Educ. Technol. Res. Dev., vol. 51, no. 2, p. 57, 2003, doi: 10.1007/BF02504526.

[57] R. Ward, "John Dewey: Rethinking our Time," Newsl. Soc. Adv. Am. Philos., 2000, doi: $10.5840 /$ saap2000288729.

[58] K. Johnston, F. Hadley, and M. Waniganayake, "Practitioner inquiry as a professional learning strategy to support technology integration in early learning centres: Building understanding through Rogoff's planes of analysis," Prof. Dev. Educ., 2020, https://doi.org/10.1080/19415257.2019.1647871

[59] S. A. Nonis and G. I. Hudson, "Developing and assessing critical thinking skills in marketing students: The power of making explicit problem-solving processes,” J. Educ. Bus., vol. 94, no. 3, pp. 195-203, 2019. https://doi.org/10.1080/08832323.2018.1504737

[60] C. Y. Chang and Y. H. Weng, "An exploratory study on students' problem-solving ability in earth science," Int. J. Sci. Educ., vol. 24, no. 5, pp. 441-451, 2002, doi: 10.1080/09500690110066502.

[61] Z. Bhatti, M. Bibi, and N. Shabbir, "Augmented Reality based Multimedia Learning for Dyslexic Children," in 2020 3rd International Conference on Computing, Mathematics and Engineering Technologies: Idea to Innovation for Building the Knowledge Economy, iCoMET 2020, 2020, pp. 1-7. https://doi.org/10.1109/icomet48670.2020.9073879

[62] V. Cathro, "An odyssey of virtual global team activity in the experiential learning environment of the Global Enterprise Experience (GEE)," Comput. Human Behav., vol. 107, p. 105760, 2020. https://doi.org/10.1016/j.chb.2018.10.026

[63] C. S. Che Dalim, M. S. Sunar, A. Dey, and M. Billinghurst, "Using augmented reality with speech input for non-native children's language learning,” Int. J. Hum. Comput. Stud., vol. 134, pp. 44-64, 2020. https://doi.org/10.1016/j.ijhcs.2019.10.002

[64] A. Moore et al., "Comparative usability of an augmented reality sandtable and 3D GIS for education," Int. J. Geogr. Inf. Sci., vol. 34, no. 2, pp. 229-250, 2020, doi: 10.1080/13658816.2019.1656810.

[65] S. J. Priniski, C. A. Hecht, and J. M. Harackiewicz, "Making Learning Personally Meaningful: A New Framework for Relevance Research,” J. Exp. Educ., vol. 86, no. 1, pp. 11-29, 2018. https://doi.org/10.1080/00220973.2017.1380589

[66] R. Grossman, "Structures for Facilitating Student Reflection," Coll. Teach., vol. 57, no. 1, pp. 15-22, 2009, doi: 10.3200/CTCH.57.1.15-22.

\section{Authors}

Alfyananda Kurnia Putra is lecturer in Department of Geography, Social Science Faculty, Universitas Negeri Malang, Indonesia. He expert in education, research and community services in education area.

Sumarmi is professor in Department of Geography, Social Science Faculty, Universitas Negeri Malang, Indonesia. She also part of the Dean Board of Social Science Faculty in State University of Malang.

Alfi Sahrina is lecturer in Department of Geography, Social Science Faculty, Universitas Negeri Malang, Indonesia. She expert in research for geography education. 
Azni Fajrilia is student of postgraduate program in Geography Education, Social Science Faculty, Universitas Negeri Malang, Indonesia.

Muhammad Naufal Islam is student of undergraduate program in Geography Education, Social Science Faculty, Universitas Negeri Malang, Indonesia.

Batchuluun Yembuu, is a professor in Geography Education at Mongolian National University of Education. He focuses on Geography education and learning, Geography Education curriculum studies and Geography textbook development. He also does a lot of research in the field of physical geography and education for climate change.

Article submitted 2021-01-05. Resubmitted 2021-02-19. Final acceptance 2021-02-21. Final version published as submitted by the authors. 